\title{
Contributions of MNEs to poverty alleviation through CSR programs: Bangladesh perspective
}

\author{
Nazamul Hoque, Mohammad Aktaruzzaman Khan \\ and Mohammad Zahid Hossain Bhuiyan \\ Department of Business Administration \\ International Islamic University Chittagong (IIUC), Bangladesh
}

\begin{abstract}
This study examines the contribution of CSR programs of multinational enterprises (MNEs) operating in Bangladesh in the poverty alleviation. The authors employed a mixed-method approach to collect qualitative data by interviewing executives of ten MNEs while for quantitative data annual reports, websites, and articles were consulted. Results depicted insignificant contribution of MNEs in poverty alleviation by their corporate social responsibility (CSR) initiatives. The average contribution of sample MNEs stand at only 0.52 per cent of profits after tax to CSR programs, ranging from $2.96 \%$ to $0.15 \%$. The study reveals that most of the MNEs are not contributing as per their financial capacity and they lack a policy of donating a reasonable portion of profit to CSR along with poverty alleviation priority. The study suggests that government of Bangladesh must act sincerely and deliberately for active involvement of MNEs in CSR programs helpful for poverty alleviation by necessary policy framework and motivational supports with a view to accelerate the poverty alleviation movement for a happy, prosperous, and progressive Bangladesh.
\end{abstract}

Keywords CSR, Poverty alleviation, MNEs, Bangladesh

Paper type Research paper

\section{Introduction}

Economic inequality is enhancing gradually in the world (Ortiz \& Cummins, 2011). In this regard, the World Bank estimated that around 3000 million people are living in poverty and because of the sluggish economic growth rates as well as worldwide economic meltdown around forty six million more people will experience to live only on US $\$ 1.25$ per day (Ali \& Hatta, 2014; Hoque, Khan, \& Mohammad, 2015; World Bank, 2010) despite having an ambitious goal of poverty reduction set by the World leaders at the Millennium Summit of September 2000. Similarly, Oxfam (2015) estimated that 50\% of the world's wealth is owned by $1 \%$ richest. It means only

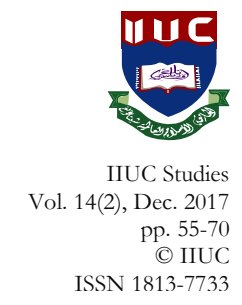


one percent rich people of the world possess more wealth than the other ninety-nine percent population of the world. In 2017, it is reported that just eight men owned the same wealth as half (3.6 billion people) of the world population (Oxfam, 2017). In January 2018, it is further reported that the richest $1 \%$ of world's population own $82 \%$ of the world's wealth (The Daily Prothom Alo, 2018). These reports show that the gap between rich and poor is alarming and far greater than had been feared. Indeed, poverty is one of the social problems of the world (Affandi \& Astuti, 2013) which creates many social problems like illiteracy, sanitation, malnutrition, early marriage, corruption, sin and crimes (Hassan, 2006; Pramanik, 1994). So, around the world poverty has become one of the issues for government, civil society, social thinkers, NGOs and business enterprises.

In parallel, in spite of having poverty in the world, many business organizations are generating enormous profit. For instance; the total amount of profit of 500 leading corporations of the world was around $\$ 2000$ billion in the financial year 2013, a twenty seven percent up from the financial year 2012 (Fortune Magazine, 2014). It plainly indicates that most of the profit making business organization of the world are focusing on the wealth maximization (Chrisman, Chua, \& Zahra, 2003; Collier, 2008; Hoque \& Sobhani, 2014; Poitras, 1994; Steidlmeier, 1993) and poverty alleviation remained unanswered (Prieto-Carrón, Lund-Thomsen, Chan, Muro, \& Bhushan, 2006) and narrowly addressed within corporate social responsibility (Hoque \& Sobhani, 2014; Hoque, Rahman, Molla, Noman, \& Bhuiyan, 2018) framework of Multinational business enterprises (MNEs). Consequently, profit maximizing business enterprises have been unable to solve problems like inequality and poverty (Hoque \& Sobhani, 2014; Yunus, 2009) from the societies of developing countries, which they could solve because of having both financial capabilities as well as managerial skills to undertake many projects for removing poverty as part of their CSR initiatives (Hoque \& Sobhani, 2014). Fortunately, significant number of global companies are practicing CSR activities (McKinsey \& Company, 2009), and nowadays, CSR is a potential driving force contributing to economic development of developing countries. It facilitates in fostering education, reducing poverty, promoting equality, and sustainable development (UN, 2006). It is assumed that the CSR activities in many underdeveloped and developing countries have been largely initiated by MNEs (Quazi, Rahman, \& Keating, 2007). A Multinational Enterprise (MNE) is that company which generally operates manufacturing and services facilities in many countries rather than only one country. In general, headquarter of MNE situates in home country 
MNEs to poverty alleviation 57

but its operations are spread over in different host countries. A company may lend its patents, licenses, and administrative and managerial expertise and services to business organization in host countries or it may directly invest funds in host countries. Therefore, MNEs may do business activities in different foreign countries in the form of franchises, joint ventures, branches and subsidiaries etc.

Bangladesh is one of the countries in the world where still a significant number of people live in poverty. Consequently, many social problems such as malnutrition, illiteracy, social crimes and offenses are occurring and prevailing in Bangladesh. In 2013, Central Intelligence Agency Fact book reported that 31.51\% people of Bangladesh live in abject poverty. On the contrary, Hoque and Sobhani (2014) observed that the MNEs in Bangladesh are generating super profit. This is due to the fact that those MNES have both managerial capacity and financial strength. It is said that the CSR activities of Bangladesh is shaped and motivated mostly by MNEs. Consequently, the business organizations of Bangladesh are increasingly moving from the strong legal and economic dominion of CSR to the moral and optional aspects (Quazi, Rahman, \& Keating 2007). Fortunately, of late, following the footsteps of MNEs, almost all banks and many business enterprises of Bangladesh are engaged at different degree in different social activities which are more or less generating benefits for the community of the Bangladesh. Of course, numerous business enterprises have now CSR activities with a view to entertaining the demand of various stakeholders of the society. According to Quazi et al. (2007) the business enterprises of Bangladesh are now thinking over CSR issues and they are carrying out CSR projects and activities to ensure justice within their customers, employees, the community and pertinent stakeholders though in many cases the motivation is philanthropic.

In Bangladesh, there are many MNEs from all over the world due to globalization as well as favorable government policy. These MNEs are performing various types of CSR projects for the benefits of society of Bangladesh. Nevertheless, the impact of CSR activities are still questionable and debatable whether those activities fetch any significant change in a developing country in terms of poverty reduction, and environmental sustainability (Dobers \& Halme, 2009), as the long-term results are unexplored yet (Halme \& Laurila, 2009). So, this study is an initiative to investigate the contribution of CSR programs of multinational business enterprises (MNEs) operating in Bangladesh with especial reference to poverty alleviation. 


\section{Literature review}

There is a continuing debate about the organizations involvement in different activities relating to social and environmental issues beyond the profit motive of business enterprises. In the $20^{\text {th }}$ century, business organizations were paying poor concentration to the societal issues because of paying more focus on the profit maximization. In fact, in the mid of the $21^{\text {st }}$ century the world experienced the emergence of CSR as part of vision statements and corporate strategies. At that time the term CSR was being used as a tool of marketing to build the image and to promote their products. Nevertheless, now, society expects that business organizations should not only comply with rules and regulations. Therefore, business is likely to recognize and endorse new-fangled or growing ethical and moral norms being institutionalized in society (Caroll, 1999). Interestingly, the literature reveals that while many organizations of the world have assumed CSR to endorse balanced and sustainable development, the rest have deliberately incorporated CSR initiatives in order to meet various stakeholders' demand such as consumers, investors, employees, community, environment, and government (Hoque \& Sobhani, 2014).

CSR has been found to have an advantageous impact on the performance of business (Ragodoo, 2009). Surveying 1,254 business executives on the global companies, The Economist Intelligence Unit (2008) concluded that the company growth rate and social/environmental concern was positively correlated. Similarly, IBM (2008) found that organizations having good financial performance have positive attitudes towards involving more CSR activities than that of others organizations having poor financial performance. With the passage of time, CSR has become a widely-practiced notion by business entrepreneurs in the world. Billions of dollars are being spent in the name of CSR and business organizations are allocating fund for implementing different programs under the banner of CSR with a view to generate multidimensional benefits both for business and society.

However, about eight million people of the world expire due to poverty, eight hundred million people starve daily, and more than hundred million children cannot go to primary school due to poverty reason (Net Aid, 2008), despite the declaration of United Nations (UN) of 1948 declaring that every single individual has the right to food, health, education, work, well-being and shelter. Therefore, the vision of UN's (2006) for "a planet having less hunger, poverty, and disease, better prospects of survival for mothers and their babies, equal opportunities for women, better educated children, and a healthier environment" cannot be 
MNEs to poverty alleviation 59

attained only through global aid. To manage the poverty of the world, a multi-pronged strategy and wholehearted supports of the business organization is essential (Ragodoo, 2009). The role and bounty of business organizations can make the world a suitable residence. Visser made a remarkable contribution to the prevailing CSR literature by explaining CSR in the context of developing countries (Visser, 2007). According to Visser, CSR is to be defined from the perspective of social, economic, cultural, religious, and political context of different countries. He argued that a business organization can significantly contribute to the ethical, social, economic, governance, labor and environmental setting of the developing countries in which they work, while remaining responsive to existing historical, religious, and cultural contexts. Therefore, it is the responsibility of business organizations too to address the issue of the society. After an extensive study in the context of Indonesian society, Graham, Fitzmaurice, Bell, \& Cairns (2004) observed that the business community is not addressing the socio-economic issues, rather are focusing on the interest of business. They argued that the business community can contribute to poverty-alleviation and equity-enhancement.

However, contribution in the poverty alleviation does not indicate that business organizations always contribute to philanthropy and charity without considering its sustainability and growth (Ragodoo, 2009). In his interesting book, the Fortune at the Bottom of the Pyramid, Prahalad (2004) argues that doing business can help tremendously in managing global poverty by an intelligent way. He rightly points out that during the past 50 years many attempts have been made by the world bodies such as World Bank, donor nations, aid agencies, and governments which eventually have demonstrated to be fruitless in eradication of poverty, as it exists vastly in the front position and the concern of one and all.

Unfortunately, very few studies have attempted so far to examine the relationship between CSR and poverty (Christian Aid, 2004; Engineers against Poverty, 2004; Jenkins, 2005; Oyen, 2005; RISC, 2004; Rohregger, 2006). More particularly, very limited research have been conducted in underdeveloped as well as in developing countries. Kivuitu, Yambayamba and Fox (2005) conducted a study in Kenya and Zambia with a view to investigate the contribution of CSR programs on the socio-economic development. They found that the business organizations of those countries were mostly engaged in health care and education-related activities. Their CSR belief is primarily focuses on a notion that every business organization should give something back to the society. Similarly, many research have also investigated that CSR should address the country-specific issues on priority basis (Burton, Farh, \& Hegarty, 2000; 
Edmondson \& Carroll, 1999; Pinkston \& Carroll, 1994; Ragodoo, 2009; Visser, 2007). The broadly accepted pyramid of Caroll is, therefore, reexamined from the perspective of developing countries, as presented in Figure 1.

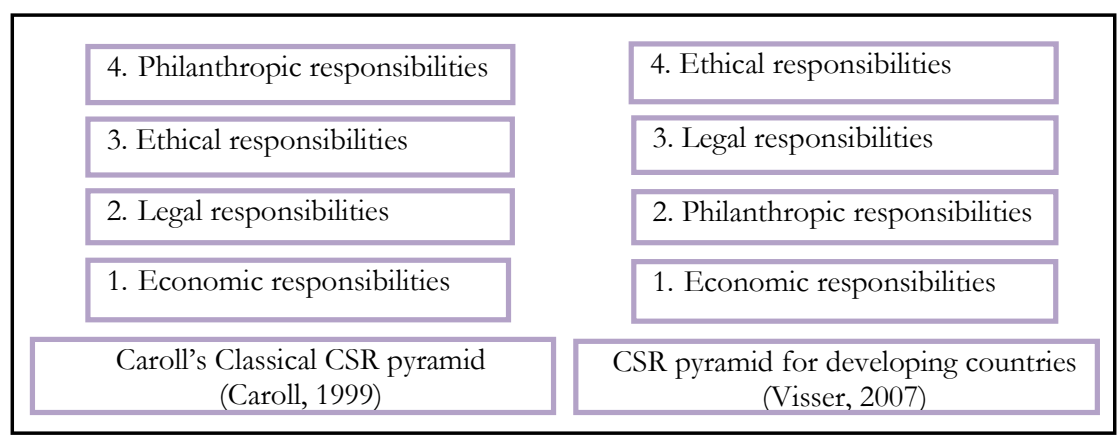

Figure 1: CSR pyramid for developing and developed countries

Though economic responsibilities is rated as the top priority yet philanthropic responsibility has been rated as second important priority, followed by legal responsibilities and ethical responsibilities. This indicates that the people of developing country expect that business enterprises should do and prefer charity and philanthropy before legal responsibilities. This is due to the fact that many social problems like malnutrition, illiteracy, poverty, and pollution are prevailed at high level. If, business organization perform their philanthropic responsibilities those problems can be reduced from the society of developing countries. Crane and Matten (2007) observed that in the context of European countries too CSR understanding and expectation varies tremendously because of variation in culture and level of economic development.

\section{CSR and poverty in Bangladesh}

In Bangladesh, 31.51\% people live in poverty and $40 \%$ people are unemployed (Central Intelligence Agency Factbook, 2013). Business enterprises are critical to the socio-economic development of any society in which they run their business operations because they not only mobilizes resources but also create employment opportunity for the people of society (Ragodoo, 2009). Now, business organizations are trying increasingly to integrate CSR activities as a business management strategy. Accordingly, the business organization of Bangladesh is increasingly moving from the strong legal and economic dominion of CSR to the moral and optional aspects (Quazi, Rahman, \& Keating, 2007). In Bangladesh, 100 percent of the Banks are engaged at different degree in 
MNEs to poverty alleviation 61

different social activities which are more or less generating benefits for the community of Bangladesh. For example, the all the Banks of Bangladesh as well as non-bank financial institutions have directly contributed about TK.4,422,387,450 (\$56697275) and Tk.57,501,000 (\$737192) in the year 2013 (Bangladesh Bank, 2014). Hoque and Sobhani (2014) found that the average dividend of last ten years of four sample multinational companies were $225.7 \%, 197.1 \%, 164.1 \%$, and $150 \%$ which indicate that those multinational business enterprises maximized their profit and sometimes the company earned up to $810.4 \%$ profit. It means that those profit maximizing business enterprises have paid very little or poor attention toward community interest (poor community). On the other hand, it also means that those business enterprises have both managerial skills and financial capacity in running social projects with a view to alleviation of poverty from Bangladesh. Indeed, a socially responsible company cannot make super profit that the profit maximizing business enterprises do. In spite of that many business organizations are doing CSR activities with a view to address the demand of stakeholders. Numerous business enterprises have CSR activities with a view to entertaining the demand of various stakeholders of society. According to Quazi, Rahman, and Keating (2007) the business enterprises of Bangladesh are now thinking over CSR issues and they are carrying out CSR projects and activities to ensure justice within their customers, employees, the community and pertinent stakeholders though in many cases the motivation is philanthropic. It is said that the CSR activities of Bangladesh is shaped and motivated mostly by MNCs.

However, in literature, scanty of studies have been found that investigated and explored the CSR contribution of multinational enterprises towards the poverty alleviation in Bangladesh. This study, thus, intends to contribute to the scant CSR literature in Bangladesh on the contribution of multinational business enterprises in poverty reduction. The key purposes of this study, thus, are to investigate the contribution of MNEs towards poverty alleviation in Bangladesh through their CSR initiatives. The study will also explore the answer of some research questions such as; what amount/percentage of profits MNEs are using for executing CSR programs? Who are the real beneficiaries? What are the policies of their CSR programs? Do they have any specific policy to address the poverty issues of Bangladesh? How do they supervise and monitor their CSR program? All these investigation will help to understand the insights of the CSR practices of MNEs operating in Bangladesh. 


\section{Methodology}

This study investigates the impact of CSR programs and initiatives of multinational organizations operating in Bangladesh towards poverty alleviations. For the purpose of this research, the researchers have used a research method combining both quantitative and qualitative approach called embedded design. The qualitative data have been collected by interviewing the ten policy maker and manager of sample multinational organizations employing semi-structured interview protocol and quantitative data have been collected from the annual reports of sample organizations to better understand the authentic domain of problem (Creswell \& Plano Clark, 2011). The design of interview was mostly descriptive and somewhat investigative in nature.

The selections of interviewees were determined by an aspiration to envelop an extensive range of research questions to explore the purposes and goals of CSR activities of the MNCs operating in Bangladesh. Most of our interviewees engaged in higher-ranking in the enterprises and had the accountability of handling the issues relating CSR. The managers of MNEs have been interviewed to explore the insights about multidimensional issues relating to the CSR programs relating to the social wellbeing issues of Bangladesh. Data collection was conducted during the period of December 2015 to February, 2016 employing purposive sampling technique. Initially, the authors visited the web sites of all multinational business enterprises listed in Dhaka Stock Exchange (DSE), Bangladesh and only those have been included as sample organizations where at least any information on CSR was available. Thus, organizations having no information were dropped and only ten organizations were selected as sample such as two cement companies, two pharmaceuticals, two chemical companies, one telecommunication company, one tobacco company, one Paints company, and one leather company.

During the explanatory stage, the secondary data regarding EPS, dividend and fund contributed to CSR have been collected visiting annual reports of ten sample multinational business enterprises (MNEs) of Bangladesh. The annual report has been selected as the key document is due to the reality that it is published annually and conveniently obtainable. It is to note that companies also communicate their different financial and social activities to various stakeholders through their annual reports (Gray, Javad, Power, \& Sinclair, 2001). Lastly, both collected qualitative and quantitative data were organized and interpreted by using their own style. 
MNEs to poverty alleviation 63

\section{Findings and discussion}

Total profit volume of ten sample multinational business enterprises (MNEs) are BDT35022.07 Million/\$437.78 million (Table 1). If these companies contribute $2 \%$ profit to CSR projects, a fund of Tk.700.44 million $\$ 8.75$ million would be available in a year.

Table 1: Showing total profit of 10 sample MNEs for 2014

\begin{tabular}{|c|c|c|c|c|}
\hline $\begin{array}{l}\text { Involved business } \\
\text { sector of sample } \\
\text { organization }\end{array}$ & $\begin{array}{l}\text { Profit after tax } \\
\text { in BDT(million) }\end{array}$ & $\begin{array}{c}\text { EPS } \\
\text { (in BDT) }\end{array}$ & $\begin{array}{l}\text { Face Value } \\
\text { of Share } \\
\text { (in BDT) }\end{array}$ & $\begin{array}{r}\text { Cash dividend } \\
\text { for } 2014 \\
\text { (in BDT) }\end{array}$ \\
\hline Telecommunication & 19803.28 & 14.67 & 10 & $16(160 \%)$ \\
\hline Cements-1 & 2819.80 & 2.43 & 10 & $1(10 \%)$ \\
\hline Lathers & 813.13 & 59.44 & 10 & $30(300 \%)$ \\
\hline Tobacco & 6281.92 & 104.70 & 10 & $55(550 \%)$ \\
\hline Chemicals-1 & 620.14 & 40.75 & 10 & $31(310 \%)$ \\
\hline Pharmaceuticals-1 & 1396.91 & 39.576 & 10 & $7.5(75 \%)$ \\
\hline Chemicals-2 & 129.55 & 27.42 & 10 & $40(400 \%)$ \\
\hline Paints & 1151.03 & 49.64 & 10 & $22(220 \%)$ \\
\hline Cements-2 & 1179.56 & 20.88 & 10 & $38(380 \%)$ \\
\hline \multirow[t]{2}{*}{ Pharmaceuticals-2 } & 826.75 & 68.63 & 10 & $42(420 \%)$ \\
\hline & $\begin{array}{c}\text { Total } \\
=35022.07\end{array}$ & $\begin{array}{c}\text { Average } \\
=42.46\end{array}$ & & $\begin{aligned} & \text { Average } \\
= & 282.44 \%\end{aligned}$ \\
\hline
\end{tabular}

Source: Annual reports of sample organizations

It is also seen that the range of cash dividend payment by MNEs is $10 \%$ to $550 \%$, average dividend payment is $282.44 \%$ and average earning per share (EPS) is Tk. 42.46. This sought of profit volume gives us the reminder of the statement of Milton Friedman (Friedman, 1962) who claimed that business organizations have only responsibilities towards shareholders. Therefore, business enterprises should use their resources in an efficient manner with a view to maximize the shareholders profit. Indeed, from the above information it is clearly revealed that the MNEs in Bangladesh are making huge profits consequently they have financial soundness to undertake many CSR projects relating to social wellbeing of the people of society of Bangladesh. The result of this study is also similar with the findings of previous study. The study conducted by Hoque and Sobhani (2014) found that the average dividend payment of last ten years of four sample multinational companies were $319 \%, 240 \%, 217.4 \%$, and $157 \%$ and sometimes the company earned up to $1004.7 \%$ profit.

The study also finds that the average contribution of sample MNEs towards CSR activities stands only 0.52 percent of their profits after tax. However, the range of CSR contribution varies tremendously from $2.96 \%$ to $0.15 \%$. Surprisingly, a sample organization from Pharmaceutical sector 
made highest contribution. However, excluding the contribution of that company $(2.96 \%)$, the average contribution of remaining nine sample MNEs stand at $0.25 \%$ which is very minimum and even the lower than the African country, Mauritania. Ragodoo (2009) observed that the Mauritanian business organizations on an average donated $0.68 \%$ of their profit to social causes. It is also disappointing that despite increasing profit, some companies have reduced their CSR contribution (from $0.27 \%$ to $0.17 \%$ and from $0.63 \%$ to $0.52 \%$ ).

On the other hand, regarding the CSR priorities (The CSR priorities of MNEs can be seen in Table 2) the study explores that poverty alleviation program is not included within their three most priority programs. It clearly indicates that still poverty alleviation has not been included in their priority list of CSR activities. It has been found that caring for the environment is at the top of the list (with $80 \%$ ) of MNEs operating in Bangladesh followed by education, healthcare \& sanitation and sports \& culture. However, poverty alleviation has been remaining at the fifth place. Thirty percent interviewees ( 3 out of 10 respondents) replied that poverty alleviation is in their priority list. Thus, most of MNES are poorly involved in CSR activities, especially, in the area of poverty alleviation. Interestingly, though it seems that MNEs' several other social projects are getting priority over poverty alleviation. But, if we see through the lens of human capital theory, the CSR expenditure for educating the poor can be regarded as the CSR for poverty alleviation also. According to human capital theory of Becker (Becker, 1964; Khan \& Ali, 2014, 2015), health care and education programs contributes to the poverty alleviation in the long run because; it is the hypothesis of human capital theory that economic progress and development in a country is only possible if there is investments in training and education (Cohen \& Soto, 2007; Khan \& Ali, 2014, 2015). Therefore, different CSR programs of MNEs such as education, healthcare are also contributing to poverty alleviation.

Table 2: Showing CSR priorities of ten sample MNEs

\begin{tabular}{lcr}
\hline Areas of priorities of CSR & Frequency & Percentage \\
\hline Environment & 8 & $80 \%$ \\
Education & 7 & $70 \%$ \\
Sports \& culture & 6 & $60 \%$ \\
Healthcare \& sanitation & 5 & $50 \%$ \\
Poverty alleviation & 3 & $30 \%$ \\
Others & 1 & $10 \%$ \\
\hline
\end{tabular}


MNEs to poverty alleviation 65

However, a total of 90 percent respondents replied that they can better contribute in poverty alleviation by donating more fund from profit and 60 percent managers told that their organizations have plan to be involved with different types of CSR projects aims at poverty alleviation. For example, all the MNEs operating in Bangladesh can create a fund by donating a portion of profit (say 2-5\%), from where microcredit/credit can be provided to the poor of most vulnerable areas via different charity organizations and voluntary NGOs with a view to alleviation of poverty.

Regarding the monitoring and supervision of CSR projects and activities seven managers out of 10 replied that they monitor the projects financed by them in order to make sure that funds contributed is not being plundered or misused. The monitoring and supervision is mainly done in the form of collecting the progress reports on different activities periodically relating to CSR project along with visiting the sites of the funded projects. It is also found that many MNEs are running social projects (school, healthcare, tree plantation, sanitation \& cultural programs) with their own management structure.

Regarding the contribution of a portion of profit the study finds that no company has a policy of donating a specific percent of profit to CSR activities. However, they have mentioned that CSR in their organizations is almost a regular phenomenon. In this regard, one interviewee of pharmaceutical company replied that CSR is a planned exercise having a target of improving the socio-economic condition of beneficiaries. However, the company is reluctant to disclose its CSR budget in a straightforward approach. Another interviewee has mentioned that the CSR expenditure in his company is handsome and significant. He has also mentioned that the CSR expenditure and budget of this company varies from year to year due to some pertinent factors.

Regarding the involvement of top management in CSR activities relating to poverty alleviation, 40 percent ( 4 out of 10) interviewees replied that government should come forward with policy supports along with CSR award. In this case, nine respondents (90 percent respondents) out of 10 , outlined that by providing tax concession facility, Government can ensure more active participation of MNEs in poverty alleviation movement of Bangladesh through their CSR practices.

\section{Limitations and future research}

This study is not free from some limitations. First, this study is confined to MNCs listed in DSE. Second, the study did not measure the effectiveness and efficiency of CSR programs of MNEs. In order to overcoming these shortcomings as well as getting more comprehensive 
results, future studies can be conducted including both listed as well as non-listed MNEs operating in Bangladesh. A research measuring the effectiveness and efficiency would be an interesting one.

\section{Conclusion and recommendation}

Global warming, environment degradation, poverty, and climate change are some of the global issues of concern. These global issues are not only drawing the concentration of business enterprises of the world but also Bangladesh. After analyzing the pertinent data and information the study finds that in spite of having both financial soundness and managerial capability, the sample MNCs of Bangladesh are not contributing much to the socio-economic wellbeing of Bangladesh through their CSR interventions which has been reflected through their contribution of poor amount of profit to CSR programs. It is to note that on an average the MNEs of Bangladesh have contributed only 0.52 percent of their profits after tax to CSR initiatives, which amounts to some BDT 182.12 million $(0.52 \%$ of 35022.07$)$. Surprisingly, the range of CSR contribution varies tremendously from $2.96 \%$ to $0.15 \%$. Whereas, excluding the contribution of one $(2.96 \%)$, the average contribution of remaining nine sample MNEs stand at $0.25 \%$ which is very low and even lower than the African country, Mauritania $(0.68 \%)$. In fact, through the education and healthcare projects, the MNEs are developing the human capital (via education, training, and medical treatment) of poor which ultimately, in the long run, contribute to the poverty alleviation (Becker, 1964). However, managers of the corporate world must work out with a common policy and strategy in an attempt to put poverty-reduction on top of their social agenda.

The paramount component in the success of such endeavor is the vibrant and whole-hearted involvement and sincere participation of the every single MNE both listed and non-listed in Chittagong Stock Exchange (CSE) and Dhaka Stock Exchange (DSE). The governments of the developing countries (such as Bangladesh) should play their pioneering roles, because of having the authority to formulate necessary policies and strategies to ensure active and sincere participation of MNEs in the poverty alleviation movement. The government must take vibrant initiatives to use the opportunity efficiently and effectively. In this regard it can be worth mentionable that the Companies Act, 2013 of India has made it mandatory for a certain category of companies to spend two percent of their past three years' average net profit for CSR activities. This has made India the first and only country in the world to have mandatory CSR spending (Kapoor \& Dhamija, 2017). Furthermore, every social thinker, especially the media personality, scholar and academic should play 
MNEs to poverty alleviation 67

sincere roles in developing awareness among the stakeholders (managers, founders, and shareholders) of business enterprises to play more active roles in poverty alleviation by providing more fund, managerial skills, and taking more effective CSR projects with a view to poverty alleviation.

\section{References}

Affandi, A., \& Astuti, D. P. (2013). Dynamic model of Ibn Khaldun theory on poverty: Empirical analysis on the poverty in majority and minority Muslim population after the financial crisis. Humanomics, 29(2), 136-160.

Ali, I., \& Hatta, Z. A. (2014). Zakat as a poverty reduction mechanism among the Muslim community: Case study of Bangladesh, Malaysia, and Indonesia. Asian Social Work and Policy Review, 8(1), 59-70.

Bangladesh Bank. (2014). Review of CSR activities of financial sector 2013. Retrieved from www.bb.org.bd.

Becker, G. (1964). Human capital: A theoretical and empirical analysis with special reference to education. Chicago: The University of Chicago Press.

Burton, B. K., Farh, J. L., \& Hegarty, W. H. (2000). A cross-cultural comparison of corporate social responsibility orientation: Hong Kong vs United States students. Teaching Business Ethics, 4(2), 151-167.

Caroll, A. B. (1999). Corporate social responsibility: Evolution of a definitional construct. Business and Society, 38(3), 268-295.

Central Intelligence Agency Factbook. (2013). Country socio-economic data. Washington, DC: The online Factbook.

Chrisman, J. J., Chua, J. H., \& Zahra, S. A. (2003). Creating wealth in family firms through managing resources: Comments and extensions. Entrepreneurship Theory and Practice, 27(4), 359-365.

Christian Aid. (2004). Behind the Mask: The real face of corporate social responsibility. London: Christian Aid.

Cohen, D., \& Soto, M. (2007). Growth and human capital: Good data, good results. Journal of Economic Growth, 12, 51-76.

Collier, P. (2008). The bottom billion why the poorest countries are failing and what can be done about it. Oxford: Oxford University Press.

Crane, A., \& Matten, D. (2007). Business Ethics (2nd ed.). Oxford: Oxford University Press.

Creswell, J. W., \& Clark, V. L. P. (2011). Designing and conducting mixed research methods ( $2^{\text {nd }}$ ed.). London: Sage.

Dobers, P., \& Halme, M. (2009). Corporate social responsibility and developing countries. Editorial Corporate Social Responsibility and Environmental Management, 16, 237-249. 


\section{IIUC Studies, 14(2)}

Economic Intelligence Unit. (2008). Doing good: Business and the sustainability challenge. The Economist, January.

Edmondson, V. C., \& Carroll, A. B. (1999). Giving back: An examination of the philanthropic motivations, orientations and activities of large black-owned businesses. Journal of Business Ethics, 19(2), 171-179.

Engineers against Poverty. (2004). Corporate social responsibility as a strategy for poverty reduction: Fact or fiction? Conference report, engineers against poverty. London, October 13.

Fortune Magazine. (2014). Retrieved November 2, 2014, from http:/ / fortune.com/global500/?iid=G500_sp_full

Friedman, M. (1962). The social responsibility of business is to increase its profits. The New York Times, September, 126.

Graham, W. J., Fitzmaurice, A. E., Bell, J. S., \& Cairns, J. A. (2004). The familial technique for linking maternal death with poverty. The Lancet, 363(9402), 23-27.

Gray, R., Javad, M., Power, D. M., \& Sinclair, C. D. (2001). Social and environmental disclosure and corporate characteristic: A research note and extension. Journal of Business Finance and Accounting, 28(2) 327-356.

Halme, M., \& Laurila, J. (2009). Philanthropy, integration or innovation? Exploring the financial societal outcomes of different types of corporate responsibility. Journal of Business Ethics, 84(3), 325-339.

Hassan, M. K. (2006, November 24-26). The role of zakat in poverty alleviation in Bangladesh. Paper presented at a conference, 24-26 November 2006.

Hoque, N., \& Sobhani, F. A. (2014, December 19-20). Developing social business enterprise: A corporate social responsibility (CSR) approach. Paper presented at the $7^{\text {th }}$ IIUC International Conference, Chittagong, Bangladesh.

Hoque, N., Khan, M. A., \& Mohammad, K. D. (2015). Poverty alleviation by Zakah in a transitional economy: A small business entrepreneurial framework. Journal of Global Entrepreneurship Research, 5(1), 7. DOI 10.1186/s40497-015-0025-8

Hoque, N., Rahman, A. R. A., Molla, R. I., Noman, A. H. M., \& Bhuiyan, M. Z. H., (2018). Is corporate social responsibility pursuing pristine business goals for sustainable development? Corporate Social Responsibility and Environmental Management, 25(6), 1130-1142.

Hoque, N., Uddin, M. R., Ibrahim, M., \& Mamun, A. (2014). Corporate social responsibilities (CSR) as a means of materializing corporate vision: A Volvo Group approach. Asian Social Science, 10(11), 258-268.

IBM. (2008, February 12). Attaining sustainable growth through CSR. Retrieved from http://www-935.ibm.com/services/us/index.wss/ibvstudy/gbs/a1029293 
Jenkins, R. (2005). Globalization, corporate social responsibility and poverty. International Affairs, 81(3), 525-540.

Kapoor, G. K., \& Dhamija, S. (2017). Mandatory CSR spending-Indian experience. Emerging Economy Studies, 3(1), 98-112.

Khan, M. A., \& Ali, A. J. (2014). The role of training in reducing poverty: The case of the ultra-poor in Bangladesh. International Journal of Training and Development, 18(4), 271-281. DOI: 10.1111/ijtd.12041

Khan, M. A., \& Ali, A. J. (2015). Do non-governmental organisations' socioeconomic and training programmes improve disaster prevention capacity of their beneficiaries? International Social Work, 58(3), 401-420. DOI: $10.1177 / 0020872815570074$

Kivuitu, M., Yambayamba, K., \& Fox, T. (2005). How can corporate social responsibility deliver in Africa? Insights from Kenya and Zambia. London: IIED.

McKinsey and Company. (2009). Global survey results-valuing corporate social responsibility. Retrieved February 2015, from www.mckinseyquarterly.com/Valuing_corporate social responsibility_ McKinsey_Global_Survey_Results_2309

NetAid. (2008). Available at: www.netaid.org/search.jsp

Ortiz, I., \& Cummins, M. (2011). Global inequality: beyond the bottom billion - a rapid review of income distribution in 141 countries. New York: UNICEF.

Oxfam. (2015). World Economic Forum summit in the ski resort of Devos. Retrieved October 2017, from http://www.theguardian.com/business/2015/jan/19/global-wealth-oxfaminequality-davos-economic-summit-switzerland

Oxfam. (2017). Just 8 men own same wealth as half the world. Retrieved February 15, 2018, from https://www.oxfamamerica.org/explore/researchpublications/an-economy-for-the-99-percent/

Oyen, E. (2005). The polyscopic landscape of poverty. Bergen, Norway: Research Council of Norway.

Pinkston, T. S., \& Carroll, A. B. (1994). Corporate citizenship perspectives and foreign direct investment in the US. Journal of Business Ethics, 13(3), 157-169.

Poitras, G. (1994). Shareholder wealth maximization, business ethics and social responsibility. Journal of Business Ethics, 13(2), 125-134.

Prahalad, C. K. (2004). The fortune at the bottom of the pyramid. Philadelphia, PA: Wharton School Publishing.

Pramanik, A. H. (1994). Malaysia's economic success. Selangor Darul Ehsan, Malaysia: Pelanduk Publications. 


\section{IIUC Studies, 14(2)}

Prieto-Carrón, M., Lund-Thomsen, P., Chan, A., Muro, A., \& Bhushan, C. (2006). Critical perspectives on CSR and development: What we know, what we don't know, and what we need to know. International Affairs, 82(5), 977-987.

Quazi, A., Rahman, Z., \& Keating, B. (2007). A developing country perspective of corporate social responsibility: $A$ test case of Bangladesh. Conference proceedings of the Australian and New Zealand Marketing Academy Conference (pp. 2789-2795). Dunedin, New Zealand: Australian and New Zealand Marketing Academy.

Ragodoo, N. J. F. (2009). CSR as a tool to fight against poverty: the case of Mauritius. Social responsibility Journal, 5(1), 19-33.

RISC. (2004). CSR and poverty. Retrieved from www.risc.org.uk/readingroom/csr/csr_poverty.pdf

Rohregger, B. (2006). Corporate social responsibility and poverty reduction-KEF fact sheet 4/06. Austria: Austrian Academy of Sciences.

Steidlmeier, P. (1993). The business community and the poor: Rethinking business strategies and social policy. The American Journal of Economics and Sociology, 52(2), 209-221.

The Daily Prothom Alo. (2018, February 15). The richest 1\% of world's population own $82 \%$ of the world's wealth. The Daily Prothom Alo. Retrieved from http://www.prothomalo.com/archive/2018-01-23?edition=print

United Nations. (UN) (2006). Millennium Development Goals Report 2006. UN: Brussels.

Visser, W. (2007). Corporate social responsibility in developing countries. In A. Crane, A. McWilliams, D. Matten, J. Moon, \& D. Siegel (Eds.), The oxford handbook of corporate social responsibility (pp. 473-479). Oxford: Oxford University Press.

World Bank. (2010). Poverty profile in Muslim world. Retrieved November 28, 2014, from http://www.worldbank.org

Yunus, M. (2009). Creating a world without poverty: Social business and the future of capitalism. Public Affairs.

\section{Corresponding author}

Nazamul Hoque can be contacted at: nazam_iiuc@yahoo.com 